\title{
Serious Adverse Event Reason
}

National Cancer Institute

\section{Source}

National Cancer Institute. Serious Adverse Event Reason. NCI Thesaurus. Code C105756.

The rationale for why the adverse event was reported as being serious. 